\title{
Postharvest Biological Control of Rhizopus Rot of Nectarine Fruits by Pichia membranefaciens
}

\author{
Fan Qing and Tian Shiping, Institute of Botany, Chinese Academy of Sciences, Beijing 100093 P. R. China
}

\begin{abstract}
Qing, F., and Shiping, T. 2000. Postharvest biological control of Rhizopus rot of nectarine fruits by Pichia membranefaciens. Plant Dis. 84:1212-1216.

A new yeast antagonist, Pichia membranefaciens, isolated from wounds of peach fruit, was evaluated for its biocontrol capability against Rhizopus stolonifer on nectarine fruits at different temperatures and with other treatments. P. membranefaciens at $5 \times 10^{8} \mathrm{CFU} / \mathrm{ml}$ of washed-cell suspension completely inhibited Rhizopus rot in nectarine wounds artificially inoculated with 5 $\times 10^{4}$ spores per $\mathrm{ml}$ at 25,15 , and $3^{\circ} \mathrm{C}$. A culture filtrate of the yeast antagonist failed to provide any protection against Rhizopus rot in nectarine fruits. The yeast mixed with iprodione at 100 $\mu \mathrm{g}$ a.i./ml gave better control of $R$. stolonifer than either yeast or iprodione alone. A solution of $20 \mathrm{~g} \mathrm{CaCl}_{2}$ per liter enhanced the efficacy of P. membranefaciens $\left(10^{7}\right.$ to $\left.10^{8} \mathrm{CFU} / \mathrm{ml}\right)$ as an aqueous suspension. Rapid colonization of the yeast in wounds was observed during the first 48 $\mathrm{h}$ at 25 and $15^{\circ} \mathrm{C}$. P. membranefaciens at $5 \times 10^{8} \mathrm{CFU} / \mathrm{ml}$ was effective when applied 0 to $72 \mathrm{~h}$ before the pathogen, while at $1 \times 10^{8} \mathrm{CFU} / \mathrm{ml}$, its efficacy was best when applied 24 to $48 \mathrm{~h}$ prior to inoculation with $R$. stolonifer. However, its efficacy was significantly reduced when the yeast was applied simultaneously with the pathogen, with disease incidence of $60 \%$ and lesion diameter of $37 \mathrm{~mm}$.
\end{abstract}

Additional keywords: calcium chloride, Prunus

Rhizopus rot, caused by Rhizopus stolonifer (Ehrenb.: Fr) Vuill., is one of the most destructive postharvest diseases of stone fruits in China. The spores of $R$. stolonifer are very common in the atmosphere and this infection of fruits occurs mainly at wound sites during harvest or packing. Chemical treatment is a very important method for controlling this disease $(20,25)$. However, the application of fungicides may lead to the development of fungicide-resistant strains of postharvest pathogens $(14,29)$. In addition, public concern over the presence of chemical residues in food has resulted in cancellation of some of the most effective fungicides $(1,15)$. Therefore, research has been focused on the development of management alternatives that are both effective and economically feasible $(13,14,33)$. Microbial biocontrol agents have shown promise $(13,32)$ as potential alternatives to fungicides $(6,16,27)$.

Although the biocontrol of postharvest diseases has been widely reported $(27,32)$, $R$. stolonifer has received little attention in the past $(19,21,31)$. Isolates of Kloeckera apiculata, Candida guilliermondii (21),

Corresponding author: Tian Shiping

E-mail: shiping@public.east.cn.net

Accepted for publication 26 July 2000.

Publication no. D-2000-0913-01R

(C) 2000 The American Phytopathological Society and Enterobacter cloacae (31) partially controlled postharvest Rhizopus rot of peach fruits, whereas Cryptococcus laurentii and Rhodotorula glutinis also limited Rhizopus rot in apple, table grapes, and strawberries (19). Yeasts appear to be particularly promising biocontrol agents in the postharvest environment, since production of antibiotic probably is not involved in their activity (11).

A new yeast antagonist, Pichia membranefaciens Hansen, isolated from peach fruits, was used in this study. Our objectives were to determine its effectiveness against $R$. stolonifer infection of nectarine fruits as affected by: (i) antagonist concentration; (ii) calcium chloride treatment; (iii) time of application; and (vi) combination with the fungicide iprodione.

\section{MATERIALS AND METHODS}

Pathogen inoculum. Rhizopus stoloni$f e r$, isolated from peach fruits, was maintained on potato dextrose agar (PDA). A sporangiospore suspension of the pathogen was prepared from 10-day-old culture dishes incubated at $25^{\circ} \mathrm{C}$ by flooding with $10 \mathrm{ml}$ of sterile distilled water containing $0.5 \mathrm{ml}$ of Tween 80 per liter. The spore concentration was determined with a hemacytometer and adjusted to $5 \times 10^{4}$ spores per $\mathrm{ml}$ with sterile distilled water.

Antagonists. $P$. membranefaciens was isolated from wounds of peach fruits with the method described by Wilson et al. (33). The yeast (IMI number 382465) was identified by CABI Bioscience Identification
Services (International Mycological Institute, UK). Yeast cells cultured in 250-ml Erlenmeyer flasks with $50 \mathrm{ml}$ of nutrient yeast dextrose broth (NYDB: $8 \mathrm{~g}$ of nutrient broth, $5 \mathrm{~g}$ of yeast extract, and $10 \mathrm{~g}$ of dextrose in 1 liter water) on a rotary shaker at $200 \mathrm{rpm}$ for $24 \mathrm{~h}$ at $28^{\circ} \mathrm{C}$. The cells were harvested by centrifugation at $6,000 \mathrm{rpm}$ (about 2,500 g) for $10 \mathrm{~min}$, washed twice with $0.05 \mathrm{M}$ phosphate buffer at $\mathrm{pH} 7.0$, and resuspended in distilled water. The concentration of cells in the suspension was counted with a hemacytometer and adjusted to $5 \times 10^{8} \mathrm{CFU} / \mathrm{ml}$ with sterile distilled water. Culture filtrates were prepared by centrifuging cultures of the antagonist through a $0.2-\mu \mathrm{m}$ polycarbonate membrane filter. The unwashed cells were in the 24-h culture filtrate and adjusted to 5 $\times 10^{8} \mathrm{CFU} / \mathrm{ml}$ with additional culture filtrate. The treatments were as follows: (A) $5 \times 10^{8} \mathrm{CFU}$ of unwashed culture filtrate per ml; (B) culture filtrate; and (C) $5 \times 10^{8}$ $\mathrm{CFU}$ of washed cell suspension per $\mathrm{ml}$ in sterile distilled water; (D) sterile distilled water.

Fruits. Nectarine (Prunus persica var. nectarina) fruits were harvested at a fruit firmness of $6.74 \mathrm{~kg} / \mathrm{cm}^{2}$ from Jinzhou in Liaoning province. The fruit was transported to Beijing by a refrigerator car ( 2 to $4^{\circ} \mathrm{C}$ ) soon after harvest, then placed in refrigerated storage at $0^{\circ} \mathrm{C}$. At the beginning of the biocontrol experiment, fruit firmness was 5.70 to $5.50 \mathrm{~kg} / \mathrm{cm}^{2}$ after 40 to 50 days storage at $0^{\circ} \mathrm{C}$. Fruits were disinfected with $2 \%$ sodium hypochlorite for 2 min, washed with tap water, and air dried prior to wounding.

Efficacy of $P$. membranefaciens for controlling of Rhizopus rot. A uniform 4 $\mathrm{mm}$ deep and $3 \mathrm{~mm}$ wide wound was made at the equator of each fruit (put on its side) using the tip of a sterile dissecting needle. A 30- $\mu$ l drop of above-mentioned suspensions of $\mathrm{A}, \mathrm{B}, \mathrm{C}$, or $\mathrm{D}$ was pipetted onto each wound site. Four hours later, each wound was inoculated with $15 \mu \mathrm{l}$ of a suspension of $5 \times 10^{4}$ spores of $R$. stolonifer per $\mathrm{ml}$. Fruits were air dried, then put into $400 \times 300 \times 100 \mathrm{~mm}$ plastic trays wrapped with high density polyethylene sleeve to retain high humidity (about 95\%). There were three replicate trials of 10 fruits per treatment with a complete randomization of trays in each test. The test was conducted three times. The fruits were stored at 25,15 , and $3^{\circ} \mathrm{C}$, and infection incidence and lesion diameter were observed after 4 , 6 , and 30 days. Fruits stored at $3^{\circ} \mathrm{C}$ for 30 
days were transferred to $25^{\circ} \mathrm{C}$ for 3 to 6 days in order to determine disease development during simulated shelf life. Two diameters were measured at right angles across lesions on the surface of infected fruit. Data presented are the means of lesion diameters. The lesion diameter was recorded as $75 \mathrm{~mm}$ when the lesion exceeded half of the fruit perimeter.

Effects of $\mathrm{Ca}^{2+}$ and antagonist concentrations on Rhizopus rot. To evaluate biological control activity in the presence and absence of $\mathrm{Ca}^{2+}$, cell suspensions were made in 2\% (wt/vol) and $0 \%$ (distilled water) $\mathrm{CaCl}_{2}$ solutions. Wounds were made as described above, then inoculated with $30 \mu \mathrm{l}$ of $5 \times 10^{8}, 5 \times 10^{7}, 5 \times 10^{6}, 5 \times$ $10^{5}$, and $0 \mathrm{CFU} / \mathrm{ml}$ suspensions of $P$. membranefaciens. After $4 \mathrm{~h}, 15 \mu \mathrm{l}$ of $5 \times 10^{4}$ spores per $\mathrm{ml}$ of $R$. stolonifer were added to each wound. Treated fruits were stored at $25^{\circ} \mathrm{C}$ in wrapped trays as described above. Disease incidence and severity were recorded 4 days after challenge inoculation. There were three replicates of 10 fruits (one wound per fruit) per treatment. The test was conducted three times.

Colonization of wounds by $P$. membranefaciens. Three wounds per fruit were made equidistant around the fruit "equator," then $30 \mu \mathrm{l}$ of washed-cell suspension of $P$. membranefaciens at $5 \times 10^{8}$ $\mathrm{CFU} / \mathrm{ml}$ was pipetted onto each wound. Fruit samples were taken to determine the antagonist population $1 \mathrm{~h}$ after inoculation (time 0 ) and after 7, 14, 21, and 28 days at $3^{\circ} \mathrm{C}$. The population in wounds of fruits stored at 25 and $15^{\circ} \mathrm{C}$ were sampled each day for 7 days. Yeast cells were recovered as described by Janisiewicz et al. (18). Fruits were wounded and $30 \mu \mathrm{l}$ of $5 \times 10^{8}$ $\mathrm{CFU} / \mathrm{ml}$ suspension was applied to each wound. The antagonist was recovered by removing the wound tissue, grinding it in a mortar with $0.05 \mathrm{M}$ phosphate buffer, and plating $0.1 \mathrm{ml}$ of a 10 -fold dilution on NYDA. Plates were incubated at $26^{\circ} \mathrm{C}$ for $48 \mathrm{~h}$, and colony counts were expressed as the $\log _{10}$ transformed number of cells per wound. An analysis of variance of the $\log _{10}$ transformed data was carried out for each sampling day. There were three replicates of one fruit (with three wounds) for each treatment, and the experiment was conducted twice.

Preinoculation with yeast to control Rhizopus rot. A $30-\mu l$ drop containing a suspension of $P$. membranefaciens at $5 \times$ $10^{8}$ or $1 \times 10^{8} \mathrm{CFU} / \mathrm{ml}$ was pipetted onto the wound simultaneously with the $R$. stolonifer spores $\left(5 \times 10^{4}\right.$ spores per $\left.\mathrm{ml}\right)$ or at $4,24,48$, and $72 \mathrm{~h}$ before the pathogen. After inoculation, the fruits were incubated at $25^{\circ} \mathrm{C}$, and decay development was determined after 4 days. Each treatment consisted of three replicates of 10 fruits in each experiment, and the experiment was conducted three times.

Combination of yeast and iprodione on incidence of Rhizopus rot. The efficacy of $P$. membranefaciens was compared with iprodione. The treatments were as follows: iprodione at $1,000 \mu \mathrm{g}$ a.i. $/ \mathrm{ml}$; yeast at $5 \times 10^{6} \mathrm{CFU} / \mathrm{ml}$ plus iprodione at $100 \mu \mathrm{g}$ a.i./ml; yeast at $5 \times 10^{6} \mathrm{CFU} / \mathrm{ml}$; iprodione at $100 \mu \mathrm{g}$ a.i./ml; and sterile distilled water. Each wound was inoculated with $30 \mu \mathrm{l}$ at each treatment. After 4 h, 15 $\mu \mathrm{l}$ of $R$. stolonifer at $5 \times 10^{4}$ spores per $\mathrm{ml}$ was inoculated onto each wound. Fruits were kept at $25^{\circ} \mathrm{C}$, and the incidences of Rhizopus rot were observed 4 days later. Each fruit was wounded once, with three replicates of 10 fruits each per treatment, and the experiment was conducted three times.

$P$. membranefaciens in vitro effects on $\boldsymbol{R}$. stolonifer. The effects of P. membranefaciens on spore germination and germ tube elongation of $R$. stolonifer were assessed in potato dextrose broth (PDB) by the method of Piano et al. (26). An aliquot $(100 \mu \mathrm{l})$ of $R$. stolonifer at $5 \times 10^{6}$ spores $/ \mathrm{ml}$ was transferred into a glass tube $(180 \times 16 \mathrm{~mm})$ containing $5 \mathrm{ml}$ of PDB. A $100-\mu$ l quantity of $5 \times 10^{8}, 5 \times 10^{7}, 5 \times 10^{6}$
$\mathrm{CFU} / \mathrm{ml}$ living yeast cell suspensions, culture filtrate, or autoclaved $5 \times 10^{8} \mathrm{CFU} / \mathrm{ml}$ cell suspension was added to each tube, respectively. At least 200 spores of $R$. stolonifer per replicate were observed microscopically to determine germination rate and germ tube length after $15 \mathrm{~h}$ incubation at $25^{\circ} \mathrm{C}$ on a rotary shaker $(50$ rpm). Treatments were replicated three times, and the test was conducted two times.

Statistical analysis. All statistical analyses were performed with SAS (SAS Institute, Cary, NC). To test for the effect of the treatment, the data were analyzed by one-way analysis of variance (ANOVA). Means were separated with the StudentNewman-Keuls.

\section{RESULTS}

Efficacy of $P$. membranefaciens for controlling of Rhizopus rot. The highest level of control of Rhizopus rot was achieved with $5 \times 10^{8} \mathrm{CFU}$ of washed yeast cells per $\mathrm{ml}$, which completely inhibited lesion development of $R$. stolonifer in nectarine fruit at all temperatures (Fig. 1). The infection incidence and lesion diameter of fruit treated by cell-culture filtrate suspension were $30 \%$ and $16 \mathrm{~mm}$ after 4 days at $25^{\circ} \mathrm{C}, 20 \%$ and $6 \mathrm{~mm}$ after 6 days at $15^{\circ} \mathrm{C}$, respectively, which were significantly lower than those in washed cell suspension $(P<0.01)$. There was a significant difference between cell-culture filtrate suspension and washed cell suspension at 25 and $15^{\circ} \mathrm{C}(P<0.01)$. The culture filtrate did not inhibit the development of Rhizopus rot at 25 and $15^{\circ} \mathrm{C}$ with infection incidence of $100 \%$, but the infection incidence (20\%) was significantly reduced compared with the control $(80 \%)$ in $3^{\circ} \mathrm{C}$ storage at $25^{\circ} \mathrm{C}$ simulated shelf study $(P<$ $0.01)$. No infection incidence occurred for all treated fruits after 30 days storage at $3^{\circ} \mathrm{C}$.

Effects of $\mathrm{Ca}^{2+}$ and antagonist concentrations on Rhizopus rot. Significant

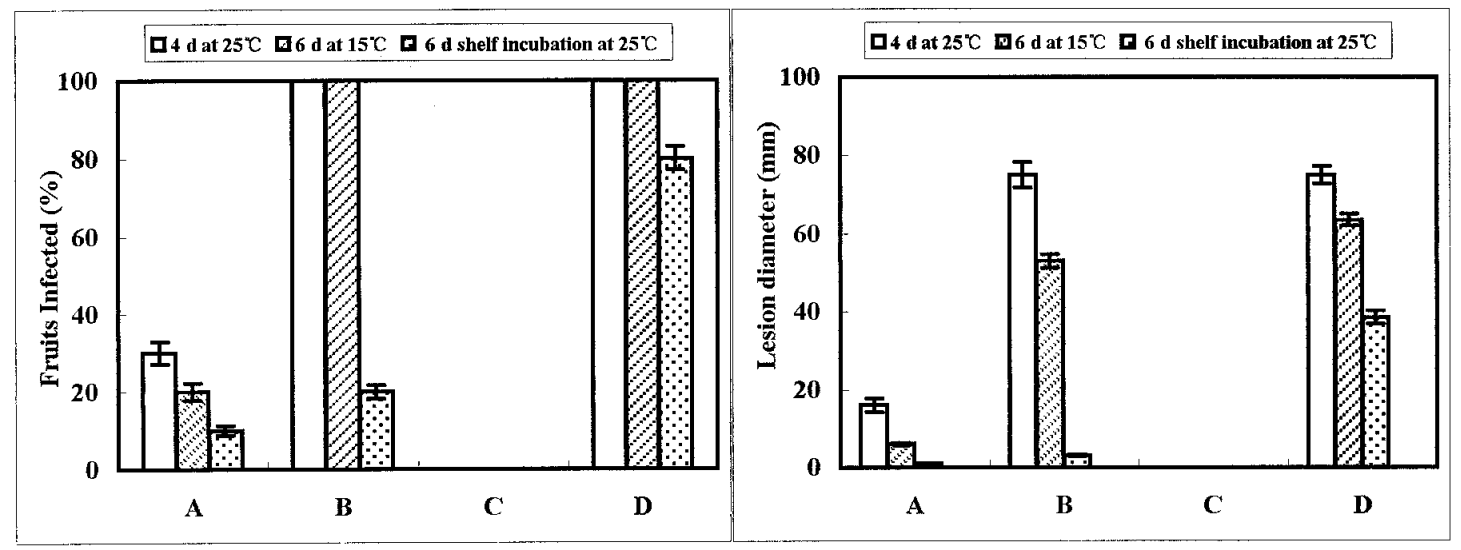

Fig. 1. Inhibition of Rhizopus rot of nectarine fruits as affected by various treatments of the antagonist. Each value is the mean from 30 inoculation sites. $\mathrm{A}=5 \times 10^{8} \mathrm{CFU}$ of Pichia membranefaciens per $\mathrm{ml}$ in $24 \mathrm{~h}$ culture filtrate; $\mathrm{B}=$ culture filtrate; $\mathrm{C}=5 \times 10^{8} \mathrm{CFU}$ suspension of washed cells of Pichia membranefaciens per $\mathrm{ml}$; $\mathrm{D}=$ sterile distilled water. Vertical bars represent standard error. Lesion diameters (right) and infected wounds (left) were measured after 4 days incubation at $25^{\circ} \mathrm{C}, 6$ days incubation at $15^{\circ} \mathrm{C}$, and 30 days storage at $3^{\circ} \mathrm{C}$ followed by 6 days at $25^{\circ} \mathrm{C}$. 
effects of $\mathrm{Ca}^{2+}$ on the inhibition of Rhizopus rot were observed. Infection incidence and lesion diameter of fruits treated with $2 \% \mathrm{CaCl}_{2}$ were significantly lower than for those treated with water at all yeast concentrations except at $5 \times 10^{8}$ $\mathrm{CFU} / \mathrm{ml}$ where both treatments completely controlled Rhizopus rot $(P<0.01)$ (Fig. 2). In addition, there were significant negative relationships between infection severity and yeast concentrations at both 0 and $2 \%$ $\mathrm{CaCl}_{2}$. At the lowest concentration $\left(5 \times 10^{5}\right.$ $\mathrm{CFU} / \mathrm{ml}$ ), the infection incidence and lesion diameter were significantly lower than in the control $(P<0.01)$.

Colonization of wounds by $P$. membranefaciens. The populations of $P$. membranefaciens in drop-inoculated wounds in fruits increased rapidly. At the beginning of the experiment (time 0), the yeast population was $3.2 \times 10^{6} \mathrm{CFU}$ per wound, and increased to $1.8 \times 10^{7} \mathrm{CFU}$ at $25^{\circ} \mathrm{C}$, $2.5 \times 10^{7} \mathrm{CFU}$ at $15^{\circ} \mathrm{C}$, and $6.8 \times 10^{6} \mathrm{CFU}$ at $3^{\circ} \mathrm{C}$ per wound within the first 2 days (Fig. 3), then stabilized thereafter $(1.8 \times$ $10^{7}$ to $8.5 \times 10^{7} \mathrm{CFU}$ per wound at 25 and $15^{\circ} \mathrm{C}, 6.8 \times 10^{6}$ to $2.9 \times 10^{7} \mathrm{CFU}$ per wound at $3^{\circ} \mathrm{C}$ ). Temperature and incubation time also affected population of the antagonist in wounds. The highest populations of the antagonist in wounds were $8.3 \times 10^{7} \mathrm{CFU}, 7.7 \times 10^{7} \mathrm{CFU}$, and $3.0 \times 10^{7} \mathrm{CFU}$ per wound after incubation for 4 days at $25^{\circ} \mathrm{C}, 6$ days at $15^{\circ} \mathrm{C}$, and 28 days at $3^{\circ} \mathrm{C}$, respectively, which were 26.3 , 24.4 , and 9.5 times greater than at the beginning of the experiment.

Preinoculation with yeast to control Rhizopus rot. Complete control of Rhizopus rot was achieved with application of $P$. membranefaciens at $1 \times 10^{8}$ $\mathrm{CFU} / \mathrm{ml}$ both at 24 and $48 \mathrm{~h}$ before inoculation with the pathogen. The biocontrol efficacy was reduced when the antagonist was applied at the same time as the pathogen or $72 \mathrm{~h}$ before the pathogen. The infected wounds and lesion diameter were $60 \%$ and $37 \mathrm{~mm}$ at $0 \mathrm{~h}, 70 \%$ and $5 \mathrm{~mm}$ after $72 \mathrm{~h}$, respectively (Table 1). Preinoculation with $P$. membranefaciens at $5 \times$
$10^{8} \mathrm{CFU} / \mathrm{ml}$ provided complete control of Rhizopus rot, irrespective of the time interval prior to the inoculation with $R$. stolonifer.

Effects of combination of yeast and iprodione on incidence of Rhizopus rot. Fruit infection and lesion diameters of all treatments were significantly reduced compared with the untreated control $(P<$ 0.01 ) (Table 2). Iprodione at $1,000 \mu \mathrm{g}$ a.i./ml completely controlled the disease. At a concentration of $100 \mu \mathrm{g}$ a.i./ml, control was less active than at the higher rate, with $85 \%$ infection and $60 \mathrm{~mm}$ lesion di- ameter. The concentration at $5 \times 10^{6}$ $\mathrm{CFU} / \mathrm{ml}$ partially inhibited the pathogen, with $45 \%$ infection and $38 \mathrm{~mm}$ lesion diameter. The combination of $P$. membranefaciens and iprodione $\left(5 \times 10^{6} \mathrm{CFU} / \mathrm{ml}\right.$ plus $100 \mu \mathrm{g}$ a.i. $/ \mathrm{ml})$ resulted in significantly lower infection incidence and lesion diameter than those treated singly with $5 \times$ $10^{6} \mathrm{CFU} / \mathrm{ml}$ or iprodione at $100 \mu \mathrm{g}$ a.i./ml $(P<0.01)$.

$P$. membranefaciens in vitro effects on R. stolonifer. Spore germination of $R$. stolonifer in PDB was totally inhibited with $P$. membranefaciens at $5 \times 10^{8}$
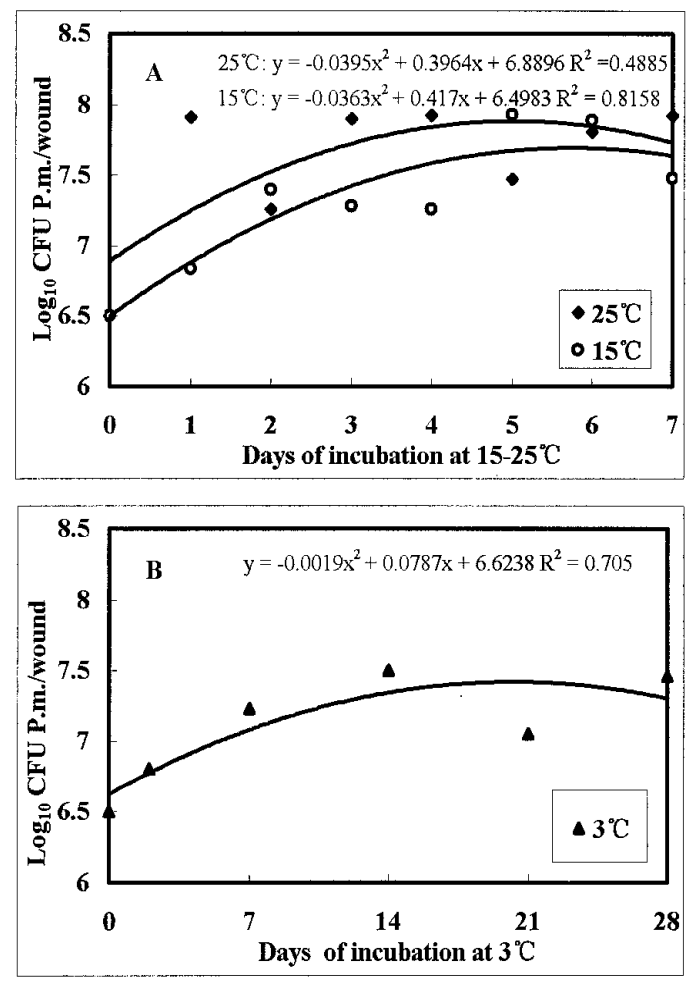

Fig. 3. Population dynamics of Pichia membranefaciens in wounds of nectarine fruits incubated at 25 to 15 (A) and $3^{\circ} \mathrm{C}(\mathbf{B})$. The fruits were wounded and $30 \mu \mathrm{l}$ of $5 \times 10^{8} \mathrm{CFU} / \mathrm{ml}$ was applied to each wound. The antagonist was recovered by removing the wound tissue, grinding it in a mortar with $0.05 \mathrm{M}$ phosphate buffer, and plating $0.1 \mathrm{ml}$ of a 10 -fold dilution on NYDA. There were three replicates of one fruit for each treatment, and the experiment was conducted twice. Data were pooled from two experiments. Bars represent standard error of the means.
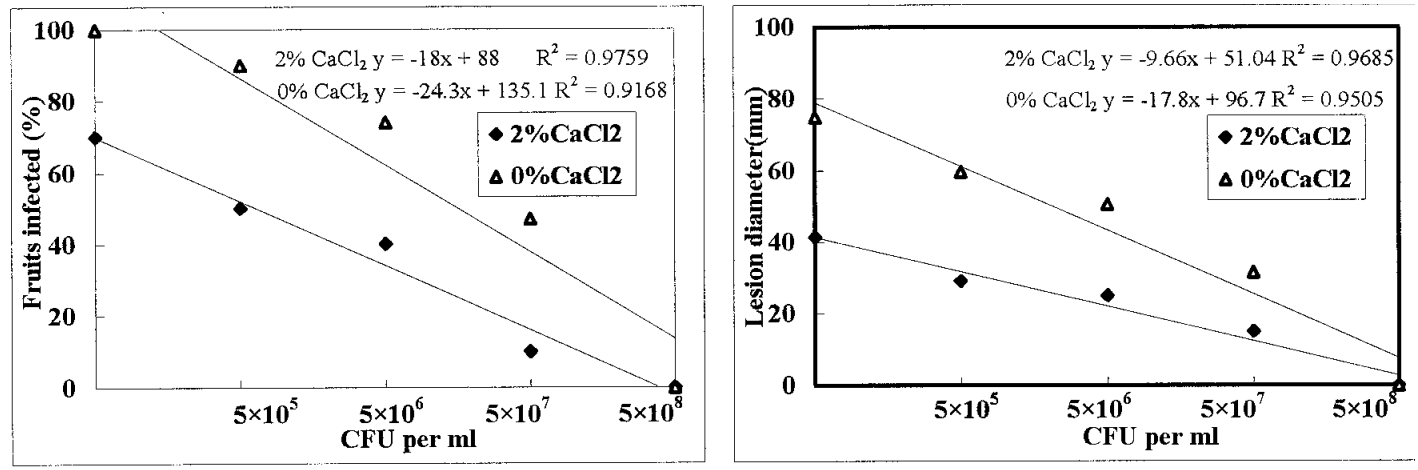

Fig. 2. Relationship between development of Rhizopus stolonifer on nectarine fruits and cell concentration of Pichia membranefaciens suspended in $2 \%$ and $0 \% \mathrm{CaCl}_{2}$. Pathogen concentration was $5 \times 10^{4}$ spores per ml. Lesion diameter (right) and percent infected wounds (left) were determined after 4 days of storage at $25^{\circ} \mathrm{C}$. There were three replicates of 10 fruits (one wound per fruit) per treatment. The test was conducted three times, and data were pooled from three experiments. Means of lesion diameter and infected wounds of the control were $75 \mathrm{~mm}$ and 100\%, respectively. 
$\mathrm{CFU} / \mathrm{ml}$ (Table 3 ). Cell suspensions of $5 \times$ $10^{7}$ and $5 \times 10^{6} \mathrm{CFU} / \mathrm{ml}$ significantly reduced germination rate and germ tube length $(P<0.01)$. Yeast cells killed by autoclaving did not affect spore germination and germ tube growth, whereas spores grown in culture filtrate had comparable germination and longer germ tube length than those in the control.

\section{DISCUSSION}

Rhizopus rot of nectarine was effectively controlled by the application of washed cells of $P$. membranefaciens. Wound areas treated with $P$. membranefaciens showed no darkening or necrosis associated with application of a concentration of $5 \times 10^{8} \mathrm{CFU} / \mathrm{ml}$ to wounds. Some reports have demonstrated that a direct relationship exists between the population density of an antagonist and the efficacy of postharvest biological control treatment $(15,16)$. Our results also showed that the antagonistic activity of $P$. membranefaciens was dependent on the concentration of the antagonist. Concentrations from $5 \times$ $10^{5}$ to $5 \times 10^{7} \mathrm{CFU} / \mathrm{ml}$ did not provide a satisfactory level of control, while $5 \times 10^{8}$ $\mathrm{CFU} / \mathrm{ml}$ completely limited rot development. The same level of control was found with $1 \times 10^{8} \mathrm{CFU} / \mathrm{ml}$ applied at 24 to $48 \mathrm{~h}$ and in $5 \times 10^{8} \mathrm{CFU} / \mathrm{ml}$ at 0 to $72 \mathrm{~h}$ before inoculation with the pathogen. These results indicated that when saturation of wound sites with $P$. membranefaciens was achieved, there was no difference between different applied concentrations, because the nutrients and/or the moisture present at the wound site limited yeast growth if the applied yeast reached saturation density (24). Our results also agreed with Piano et al. (26) using Metschnikowia pulcherrima to control gray mold of apple. When yeast was applied at a higher concentration $\left(10^{8}\right.$ to $10^{9} \mathrm{CFU} / \mathrm{ml}$ ), the biocontrol activity was not apparently related to the time of pathogen application.

Wounds treated with culture filtrate of $P$. membranefaciens developed rapidly expanding lesions, with the exception of the $3^{\circ} \mathrm{C}$ storage $/ 25^{\circ} \mathrm{C}$ simulated shelf study, where some inhibition occurred after inoculation with $R$. stolonifer. In addition, culture filtrate co-cultured with pathogen spores did not affect germination or germ tube elongation. This may indicate that $P$. membranefaciens produced no apparent antibiotic substance. This is quite different from some postharvest bacterial antagonists $(17,27)$.

Unwashed cells of $P$. membranefaciens in culture filtrate showed decreased biocontrol effectiveness compared with the washed cells, which supported the premise that competition for nutrients may play a major role in the biocontrol capability of $P$. membranefaciens against $R$. stolonifer. The importance of nutrient competition has been previously demonstrated with other antagonistic yeasts $(11,17,21,28)$. How- ever, the in vitro experiments did not show the same result as in vivo experiments where $P$. membranefaciens limited spore germination and germ tube elongation of $R$. stolonifer, even under the nutrient rich conditions of PDB, which is in agreement with the result obtained by Piano et al. (26).

Rapid colonization of $P$. membranefaciens in nectarine wounds was observed at 25,15 , and $3^{\circ} \mathrm{C}$ at an early stage and then stabilized for the remaining time, as previously observed for other antagonistic yeasts $(24,26,28)$. The initial recovery after $1 \mathrm{~h}$ was $3.2 \times 10^{6} \mathrm{CFU}$ per wound, representing only $21 \%$ recovery of $1.5 \times 10^{7}$ $\mathrm{CFU}$ per wound $\left(30 \mu \mathrm{l}\right.$ of $5 \times 10^{8}$ $\mathrm{CFU} / \mathrm{ml}$ ). However, the yeast population increased rapidly after 2 days incubation. The rapid growth of the yeast in wounds over a wide range of temperatures and its ability to control Rhizopus rot indicated that $P$. membranefaciens is well adapted to the wound environment in fruit and has considerable potential as a biocontrol agent. The ability of yeast to multiply rapidly in wounds may benefit its utilization of available nutrients, thus may facilitate biocontrol by nutrient competition.

Calcium plays an important role in controlling physiological disorders and diseases of fruits and vegetables. Application of supplemental calcium to apples is a routine practice in orchards that are prone to calcium-related nutritional disorders such as cork spot and bitter pit (2). Increased calcium content of fruits and vegetables can prolong their storage life (8). This is due mainly to the role of calcium in ameliorating physiological disorders and thus indirectly reducing pathogen activity (10). The effectiveness of calcium chloride against brown rot has been ascribed to the enhancement of host resistance by calcium (9). The role of calcium in resistance may be in interfering with the activity of pectolytic enzymes $(9,10)$. Besides, calcium can directly inhibit the pathogens. Biggs (2) found calcium salts directly suppress the bitter rot pathogens

Table 1. Effect of wounding and applying Pichia membranefaciens (P.m.) prior to the inoculation of nectarine fruits with Rhizopus stolonifer for control of Rhizopus rot

\begin{tabular}{|c|c|c|c|c|}
\hline \multirow{2}{*}{$\begin{array}{l}\text { Time between application } \\
\text { of P. } \mathbf{m} \text {. and inoculation (h) }\end{array}$} & \multicolumn{2}{|c|}{ Infected wounds (\%) } & \multicolumn{2}{|c|}{ Lesion development (mm) } \\
\hline & $5 \times 10^{8} \mathrm{CFU} / \mathrm{ml}$ & $1 \times 10^{8} \mathrm{CFU} / \mathrm{ml}$ & $5 \times 10^{8} \mathrm{CFU} / \mathrm{ml}$ & $1 \times 10^{8} \mathrm{CFU} / \mathrm{m}$ \\
\hline 0 & $0 \mathrm{~b}^{\mathrm{z}}$ & $60 \mathrm{c}$ & $0 \mathrm{~b}$ & $37 \mathrm{~b}$ \\
\hline 4 & $0 \mathrm{~b}$ & $5 \mathrm{~d}$ & $0 \mathrm{~b}$ & $2 \mathrm{~d}$ \\
\hline 24 & $0 \mathrm{~b}$ & $0 \mathrm{e}$ & $0 \mathrm{~b}$ & $0 \mathrm{e}$ \\
\hline 48 & $0 \mathrm{~b}$ & $0 \mathrm{e}$ & $0 \mathrm{~b}$ & $0 \mathrm{e}$ \\
\hline 72 & $0 \mathrm{~b}$ & $70 \mathrm{~b}$ & $0 \mathrm{~b}$ & $5 \mathrm{c}$ \\
\hline Control & $100 \mathrm{a}$ & $100 \mathrm{a}$ & $75 \mathrm{a}$ & $75 \mathrm{a}$ \\
\hline
\end{tabular}

${ }^{\mathrm{z}}$ Data were measured 4 days after inoculation with the pathogen at $25^{\circ} \mathrm{C}$. Values of each column followed by the same letter are not statistically different according to Student-Newman-Keuls $(P=$ $0.01)$.

Table 2. Effect of Pichia membranefaciens (P.m.) and chemical treatment with iprodione against Rhizopus stolonifer on nectarine

\begin{tabular}{lcc}
\hline Treatments $^{\mathbf{y}}$ & Infected wounds (\%) & $\begin{array}{c}\text { Lesion diameter } \\
(\mathbf{m m})\end{array}$ \\
\hline Iprodione, $1,000 \mu \mathrm{g} / \mathrm{ml}$ & $0 \mathrm{e}^{\mathrm{z}}$ & $0 \mathrm{e}$ \\
P.m., $5 \times 10^{6} \mathrm{CFU} / \mathrm{ml}+$ iprodione, $100 \mu \mathrm{g} / \mathrm{ml}$ & $20 \mathrm{~d}$ & $12.5 \mathrm{~d}$ \\
P.m., $5 \times 10^{6} \mathrm{CFU} / \mathrm{ml}$ & $45 \mathrm{c}$ & $38 \mathrm{c}$ \\
Iprodione, $100 \mu \mathrm{g} / \mathrm{ml}$ & $85 \mathrm{~b}$ & $60 \mathrm{~b}$ \\
Sterile distilled water & $100 \mathrm{a}$ & $75 \mathrm{a}$ \\
\hline
\end{tabular}

${ }^{\mathrm{y}}$ Lesion diameter and infected wounds were recorded after 4 days storage at $25^{\circ} \mathrm{C}$. Each treatment is the mean from 10 wounds, and data were pooled from three trials.

${ }^{z}$ Values of each column followed by the same letter are not significantly different according to Student-Newman-Keuls $(P=0.01)$.

Table 3. Effect of different concentrations of Pichia membranefaciens, autoclaved cells, and cellfree culture filtrates on spore germination and germ tube elongation of Rhizopus stonolifer

\begin{tabular}{lcc}
\hline Treatment $^{\mathrm{y}}$ & Spore germination $(\%)$ & Germ tube length $(\boldsymbol{\mu m})$ \\
\hline $5 \times 10^{6} \mathrm{CFU} / \mathrm{ml}$ & $30 \mathrm{~b}^{\mathrm{z}}$ & $22.8 \mathrm{~d}$ \\
$5 \times 10^{7} \mathrm{CFU} / \mathrm{ml}$ & $13 \mathrm{c}$ & $15.4 \mathrm{~d}$ \\
$5 \times 10^{8} \mathrm{CFU} / \mathrm{ml}$ & $0 \mathrm{~d}$ & $0.0 \mathrm{e}$ \\
$5 \times 10^{8} \mathrm{CFU} / \mathrm{ml}$ (autoclaved) & $96 \mathrm{a}$ & $205.5 \mathrm{c}$ \\
Culture filtrate & $100 \mathrm{a}$ & $249.0 \mathrm{a}$ \\
Control & $97 \mathrm{a}$ & $218.4 \mathrm{~b}$ \\
\hline
\end{tabular}

${ }^{y}$ Germination and germ tube length were measured microscopically after $15 \mathrm{~h}$ incubation at $25^{\circ} \mathrm{C}$ in potato dextrose broth. Data were pooled from two trials.

${ }^{\mathrm{z}}$ Values of each column followed by the same letter are not significantly different according to Student-Newman-Keuls $(P=0.01)$. 
by reducing germ tube growth and mycelial growth in vitro, and by reducing severity of infection of host tissue pretreated with calcium. Calcium salts have also been shown to reduce mycelial growth in vitro and reduce disease incidence and severity of peach fruits and shoots by Monilinia fructicola and Leucostoma persoonii $(3,4,5)$. Biocontrol effectiveness of antagonists could be enhanced in the presence of calcium chloride $(12,21,22)$. MacLaughlin et al. (21) found that control of gray mold and blue mold of apples was enhanced when strain 138 of Kloeckera apiculata was applied as an aqueous suspension $\left(10^{8}\right.$ $\mathrm{CFU} / \mathrm{ml}$ ) in $2 \% \mathrm{CaCl}_{2}$. Our study showed that calcium chloride significantly improved biocontrol obtained with $P$. membranefaciens. The ability of antagonists to reduce decay in the presence of $\mathrm{Ca}^{2+}$ may be partially due to nutrient competition and/or site exclusion (22), or directly inhibit spore germination and growth of pathogen through an effect on the activity of cell-wall macerating enzymes (34). The effect of calcium in this study implied that $P$. membranefaciens may be used in the future on a commercial scale for the control of postharvest diseases in fruit. However, the mode of action of calcium- $P$. membranefaciens synergism should be further studied.

The use of iprodione at a concentration of $100 \mu \mathrm{g}$ a.i./ml in combination with $P$. membranefaciens at $5 \times 10^{6} \mathrm{CFU} / \mathrm{ml}$ enhanced the biocontrol efficacy compared to the treatments used separately, similar to the results of Mari et al. (23). This approach could lead to a reduction of the chemical residue on fruit as proposed previously $(3,6,7,23,30)$. Chand-Goyal and Spotts (7) reported that better control of blue mold and brown rot were achieved by combining Cryptococcus infirmo-miniatus or $C$. laurentii with low dose of thiabendazole $(15 \mu \mathrm{g} / \mathrm{ml})$ and iprodione $(20 \mu \mathrm{g} / \mathrm{ml})$. Spotts et al. (30) found incidence of brown rot of sweet cherry was reduced from $41.5 \%$ in the control to $0.4 \%$ by combining preharvest iprodione and postharvest $C$. infirmo-miniatus treatments with modified atmosphere packaging.

P. membranefaciens, which is present in soil, fruit, wine, beer, and grape must, is generally considered to be nonpathogenic (Identification report-H37/80/YC7, CABI Bioscience Identification Services) and would be safe to use for biological control proposes. Moreover, we found that the use of $P$. membranefaciens for biocontrol is compatible with several common postharvest practices including iprodione, $\mathrm{Ca}^{2+}$ treatment, and cold storage, thus permitting an integrated control approach under commercial conditions.

\section{ACKNOWLEDGMENTS}

This research was supported by the grants from the National Natural Science Foundation of China (NNSFC-39870460) and the Chinese Academy of
Sciences. We thank J. C. David, M. Hoareau, and T. S. Caine, all from CABI Bioscience Identification Services (International Mycological Institute, UK), for their kindly help on identification of $P$. membranefaciens.

\section{LITERATURE CITED}

1. Adaskaveg, J. E., and Michailides, T. J. 1996. Cancellation of postharvest use of Rovral 50WP on stone fruit crops and other label changes of the fungicide. Cent. Valley Postharvest Newsl. 5:9-10.

2. Biggs, A. R. 1999. Effects of calcium salts on apple bitter rot caused by two Colletotrichum spp. Plant Dis. 83:1001-1005.

3. Biggs, A. R., and Peterson, C. A. 1990. Effect of chemical applications to peach bark wounds on accumulation of lignin and suberin and susceptibility to Leucostoma persoonii. Phytopathology 80:861-865.

4. Biggs, A. R., El-Kholi, M. M., and ElNeshawy, S. M. 1994. Effect of calcium salts on growth, pectic enzyme activity, and colonization of peach twigs by Leucostoma persoonii. Plant Dis. 78:886-890.

5. Biggs, A. R., El-Kholi, M. M., El-Neshawy, S., and Nickerson, R. 1997. Effects of calcium salts on growth, polygalacturonase activity, and infection of peach fruit by Monilinia fructicola. Plant Dis. 81:399-403.

6. Chalutz, E., and Wilson, C. L. 1990. Postharvest biocontrol of green and blue mold and sour rot of citrus fruit by Debaryomyces hansenii. Plant Dis. 74:134-137.

7. Chand-Goyal, T., and Spotts, R. A. 1996. Postharvest biological control of blue mold of apple and brown rot of sweet cherry by natural saprophytic yeasts alone or in combination with low doses of fungicides. Biol. Control 6:253-259

8. Conway, W. S. 1982. Effect of postharvest calcium treatment on decay of Delicious apples. Plant Dis. 66:402-403.

9. Conway, W. S., and Sams, C. E. 1984. Possible mechanisms by which postharvest calcium treatment reduces decay in apples. Phytopathology 74:208-210.

10. Conway, W. S., Sams, C. E., McGuire, R. G., and Kelman, A. 1992. Calcium treatment of apples and potatoes to reduce postharvest decay. Plant Dis. 76: 329-334

11. Droby, S., and Chalutz, E. 1994. Mode of action of biocontrol agents of postharvest disease. Pages 63-75 in: Biological Control of Postharvest Diseases of Fruits and Vegetables-Theory and Practice, C. L. Wilson and M. E. Wisniewski, eds. CRC Press, Boca Raton, FL.

12. Droby, S., Hofstein, R., Wilson, C. L., Wisniewski, M., Fridlender, B., Cohen, L., Weiss, B., Daus, A., Timar, D., and Chalutz, E. 1993. Pilot testing of Pichia Guilliermondii: a biocontrol agent of postharvest diseases of citrus fruit. Biol. Control 3:47-52.

13. E1-Ghaouth, A., Wilson, C. L., and Wisniewski, M. 1998. Ultrastructural and cytochemical aspects of the biological control of Botrytis cinerea by Candida saitoana in apple fruit. Biol. Control 88:283-291.

14. Holmes, G. J., and Eckert, J. W. 1999. Sensitivity of Penicillium digitatum and P. italicum to postharvest citrus fungicides in California. Phytopathology 89:716-721.

15. Hong, C. X., Michailides, T. J., and Holtz, B. A. 1998. Effects of wounding, inoculum density and biological control agents on postharvest brown rot of stone fruits. Plant Dis. 82:1210-1216.

16. Janisiewicz, W. J. 1988. Biocontrol of postharvest diseases of apples with antagonist mixtures. Phytopathology 78:194-198.

17. Janisiewicz, W. J., and Roitman, J. 1988.
Biological control of blue and gray mold on apple and pear with Pseudomonas cepacia. Phytopathology 78:1697-1700.

18. Janisiewicz, W. J., Usall, J., and Bors, B. 1992. Nutritional enhancement of biocontrol of blue mold on apples. Phytopathology 82:1364-1370

19. Lima, G., De Curtis, F., Castoria, R., and De Cicco, V. 1998. Activity of the yeasts Cryptococcus laurentii and Rhodotorula glutinis against post-harvest rots on different fruits. Biocontrol Sci. Technol. 8:257-267.

20. Luepschen, N. S., Rohrbach, K. G., Jones, A. C., and Peters, C. L. 1971. Methods of controlling Rhizopus decay and maintaining Colorado peach quality. Bull. Colo. State Univ. Exp. Stn. 547S.

21. MacLaughlin, R. J., Wilson, C. L., Droby, S., Ben-Arie, R., and Chalutz, E. 1992. Biological control of postharvest diseases of grape, peach, and apple with yeasts Kloeckera apiculata and Candida guilliermondii. Plant Dis. 76:470-473.

22. MacLaughlin, R. J., Wisniewski, M. E. Wilson, C. L., and Chalutz, E. 1990. Effect of inoculum concentration and salt solutions on biological control of postharvest diseases of apple with Candida sp. Phytopathology 80:456-461.

23. Mari, M., Guizzardi, M., and Pratella, P. C. 1996. Biological control of gray mold in pears by antagonistic bacteria. Biol. Control 7:30-37.

24. Mercier, J., and Wilson, C. L. 1995. Effect of wound moisture on the biocontrol by Candida oleophila of gray mold rot (Botrytis cinerea) of apple. Postharvest Bio. Technol. 6:9-15.

25. Ogawa, J. M., Sandeno, J. L., and Mathre, J. H. 1963. Comparisons in development and chemical control of decay-causing organisms on mechanical and hand-harvested stone fruits. Plant Dis. Rep. 47:129-133.

26. Piano, S., Neyrotti, V., Migheli, Q., and Gullino, M. L. 1997. Biocontrol capability of Metschnikowia pulcherrima against Botrytis postharvest rot of apple. Postharvest Biol. Technol. 11:131-140.

27. Pusey, P. L., and Wilson, C. L. 1984. Postharvest biological control of stone fruit brown rot by Bacillus subtilis. Plant Dis. 68:753-756.

28. Smilanick, J. L., and Denis-Arrue, R. 1992. Control of green mold of lemons with Pseudomonas species. Plant Dis. 76:481.

29. Spotts, R. A., and Cervantes, L. A. 1986. Populations, pathogenicity, and benomyl resistance of Botrytis spp., Penicillium spp., and Mucor piriformis in packinghouses. Plant Dis. 70:106-108.

30. Spotts, R. A., Cervantes, L. A., Facteau, T. J., and Chand-Goyal, T. 1998. Control of brown rot and blue mold of sweet cherry fruit with preharvest iprodione, postharvest Cryptococcus infirmo-miniatus, and modified atmosphere packaging. Plant Dis. 82:1158-1160.

31. Wilson, C. L., Franklin, J. D., and Pusey, P. L. 1987. Biological control of Rhizopus rot of peach with Enterobacter cloacae. Phytopathology 77:303-305.

32. Wilson, C. L., and Wisniewski, M. E. 1994. Biological Control of Postharvest Diseases of Fruits and Vegetables-Theory and Practice. CRC Press, Boca Raton, FL.

33. Wilson, C. L., Wisniewski, M. E., Droby, S., and Chalutz, E. 1993. A selection strategy for microbial antagonists to control postharvest diseases of fruits and vegetables. Sci. Hortic. (Amsterdam) 53:183-189.

34. Wisniewski, M., Droby, S., Chalutz, E., and Eilam, Y. 1995. Effects of $\mathrm{Ca}^{2+}$ and $\mathrm{Mg}^{2+}$ on Botrytis cinerea and Penicillium expansum in vitro and on the biocontrol activity of Candida oleophila. Plant Pathol. 44:10161024. 